\title{
tre PLACE of INDIGENOUS KNOWLEDGE in TERTIARY SCIENCE EDUCATION: a CASE STUDY of CANADIAN PRACTICES in INDIGENISING the CURRICULUM
}

\section{VIVIAN HAUSER, CATHERINE HOWLETT \& CHRIS MATTHEWS}

Griffith School of Environment, Nathan Campus, Griffith University, Nathan, Queensland, 4111 , Australia

\section{Abstract}

In Australia, Indigenising the curriculum is increasingly acknowledged as a possible avenue for addressing Indigenous under-representation in tertiary science education in a culturally appropriate and relevant manner. While no Australian university has implemented such a program, there is much to be learnt about the inherent complexities of Indigenising curriculum before it is pursued. In Canada, however, innovative university programs have been implemented that imbed Indigenous knowledge into the curriculum. This paper details key findings from research that sought to learn from Canadian practices in Indigenising tertiary science curriculum, by exploring the practices and experiences of two Canadian programs: Trent University's Indigenous Environmental Studies program, and Cape Breton University's Integrative Science program. ata Introduction

Education is considered a central strategy for addressing serious disparities that shape the lives of Indigenous peoples in Australia. In all levels of schooling, however, Indigenous peoples continue to be significantly underrepresented, compared to non-Indigenous students. In higher education, this predicament is especially visible in science related studies (DEST, 2006, 2008). At the heart of this issue, Snively and Williams (2006, p. 229) contend that it is the absence, or token addition, of Indigenous knowledges that renders science education inaccessible and irrelevant to Indigenous peoples. The Indigenising of curriculum is advocated as a possible avenue for addressing such disparities (Aikenhead, 2002; Bartlett et al., 2007; Cajete, 2000; Hooley, 2000; Howlett et al., 2008; McLisky \& Day, 2004, p. 4; Snively, 2006). Indigenising curriculum is considered, in part, to be the embedding of Indigenous knowledge into curriculum. It involves a process that Nakata (2007, p. 8) explains as incorporating "a discernable 'Indigenous voice' as Indigenous people insert their own narratives, critique, research, and knowledge production into the corpus".

Nakata (2007, p. 7) argues, however, that Indigenising curriculum is a complex and contested process that should not be mistaken as a simple addition of "Indigenous components to the mix". Such an exercise risks the appropriation and incorporation of Indigenous knowledges into a Western science education framework. Accordingly, Nakata (quoted in Williamson \& Dalal, 2007, p. 51) stresses that educators need to acknowledge the inherent complexities that exist at the meeting grounds of Indigenous knowledges and Western science - what Nakata refers to as the "cultural interface". Learning about this terrain in Australia is limited as no Australian university has yet implemented an Indigenised science curriculum. In Canada, however, some universities have established innovative science programs, which embed Indigenous knowledges into the curriculum. Australia is greatly positioned to learn from Canadian practices due to the historical experiences of British colonisation that bind the two. Through colonisation First Nations in both countries have survived acts of genocide, the 
dispossession of land and forced removal of their children. Amongst the most debilitating colonial tactics that has persisted is the Eurocentric education system. This system continues to exclude and marginalise an Indigenous presence, perspectives and ways of knowing within higher education. Consequently, it continues to subject Indigenous peoples to cultural and cognitive imperialism (Battiste \& Henderson, 2000 p. 85). Considering this shared colonial legacy, we suggest that Canadian practices are highly relevant to Australian educators.

In this paper we detail key findings of research, which sought to learn from Canadian practices in Indigenising tertiary science curriculum by exploring the practices of two Canadian programs: Trent University's Indigenous Environmental Studies program (IES), and Cape Breton University's Integrative Science program (IS). Specifically, we focus upon factors that have empowered Indigenous peoples and educators in negotiating a place for Indigenised curriculum in tertiary science education, along with tensions at the cultural interface of Indigenous and Western scientific knowledges that have limited this process. We introduce the methodological considerations and theoretical framework that informed the research, along with a review of current literature, and a presentation and analysis of the central research findings.

\section{Methodology}

To be appropriate and respectful for Indigenous peoples, research in Indigenous domains needs to be compatible with the historical and contemporary experiences of Indigenous peoples, and their philosophies and cosmologies (Kenny et al., 2004, p. 1; Department of Indian and Northern Affairs Canada, 2002; Smith, 1999, p. 6). Critical to this process is the recognition that research is not a neutral process, but rather, one that is culturally situated and value laden (Smith, 1999, p. 42; Kenny et al., 2004, p. 16). Indigenous peoples have, more often than not, been the subjects of research as opposed to participants, and therefore, choosing a culturally appropriate research design that works in partnership with Indigenous peoples is pivotal to the decolonisation of research methodologies (Smith, 1999, p. 39; DiGregorio et al., 1997, p. 9). To accommodate these requirements, a case study methodology, focused upon the IES and IS programs, and employing qualitative methods, was found to be most appropriate for fulfilling the research aims. Participant observation formed the central method for learning about IES experiences and practices, through attendance at a program visioning workshop. For IS at Cape Breton, a semi-structured group interview was conducted with IS staff and students. To support and verify the information gathered from participants from both groups various documents were analysed, including: pages and publications downloaded from the IES and IS program websites, an unpublished manuscript from IS staff, information gained about IES from project and conference descriptions accessed via the web, along with documents obtained from IES faculty staff.

There were a number of important ethical considerations governing this research. Indigenous peoples have an inherent right to "participate as principals or partners in research that generates knowledge affecting their culture, identity and well-being" (Castellano, 2004, p. 110). Obtaining informed consent in verbal and written formats where appropriate was an important procedure for allowing IES and IS participants to voice any concerns or queries regarding the project. In doing so, participants were also informed of their inherent freedom to withdraw from the project at any stage without prior notification, along with their authority to erase any information they felt was inappropriate to include. Subsequently, an electronic copy of the final research paper was mailed to the participants for their critical perusal and feedback.

The social construction of knowledge

According to de Vaus (2001, p. 221), case study research is fundamentally theoretical. To guide the research, social constructionism along with Foucault's ruminations on knowledge and power informed the collection and analysis of insights gained. Social constructionism, otherwise referred to as constructionism, is a contemporary Western ontological position that emerged as a response to conventional science universalisms that uphold rational and objectivist worldviews as being principal to what is deemed "legitimate" knowledge inquiries. These perspectives continue to be a dominant reasoning for determining what can be deemed as "truth" and "factual" in the production of knowledge in Westernised societies (Latour, 1993, p. 27).

Key to the constructionist thesis is the idea that there exists in the world multiple truths. While social constructionism is a Western ontological position, it was valuable for this research as it provides a space for the recognition of multiple ontologies or ways of knowing. Instead of questioning what is true, of interest to the constructionists is how we form and elucidate "what there is". For the constructionist, it is in this moment of articulation that we enter the "world of discourse", and it is precisely then that construction begins and that "this effort is inextricably woven into processes of social interchange and into history and culture" (Gergen, 1994, p. 72). This understanding of truth lends itself to the possibility of there existing in the world multiple legitimate ways of knowing. A constructionist therefore considers scientific knowledge as secular - one of many systems 
of knowledge - through the understanding that knowledge constitutes a "collective belief system" (Barnes \& Bloor, 1982, p. 45). While the constructionist stance creates a space for the recognition of ontological pluralism, it does not provide a framework for understanding how certain ways of knowing come to dominate through the power relationships inherent in knowledge production. Michel Foucault's concept of knowledge and power is useful in this regard.

\section{Foucauldian perspectives}

Foucault's concept of knowledge as a strategy of power provides a theoretical perspective of how Western science has maintained its privileged position in tertiary science institutions, and thus, how Indigenous ways of knowing in this context have been marginalised and excluded. He asserts that power, in not belonging to any structure or individual, is a strategy that is held not only by the dominator, but also the dominated and thus, it can be negative or positive (Foucault, 1979, p. 202). In enabling the operation of hegemony, such a strategy of power is not exerted through structural force, but rather through:

practices, technique and methods which infiltrate minds and bodies, cultural practices and cultivate behaviours and beliefs, tastes, desires and needs as seemingly naturally occurring qualities and properties embedded in the psychic and physical reality (or truth) of the human subject (Foucault quoted in Smart, 1986, p. 160).

Discourses are held to be a central strategy governing what can be said about truth and by whom. They are formed by a group of related statements that are not merely thoughts and themes, but "practices obeying certain rules" (Foucault, 1972, p. 138). The ways of knowing and power inherent in discourses reinforce one another to determine the circumstances under which knowledge can be deemed as truth or delegitimised and excluded. Thinking and acting outside the dominant discourse can be a difficult or even dangerous measure (Allen, 2003, p. 23). Under these conditions, individuals are positioned by discourses, and in turn, serve to implement them in society. Consequently, the dominant discourse acts as an externalising agent for Other ways of knowing that do not "fit" or make sense within the confines of the dominant discourse. The use of the term "Other" in this research is intended to problematise the circumscribing of difference between cultural groups (Blackburn, 2005, p. 264). In Westernised societies Western scientific ways of knowing constitute the dominant discourse. A direct consequence of this hegemony is that all Other knowledge systems are effectively "disqualified" in mainstream society (Smart, 1986, p. 14).
The place of Western science

It is widely agreed upon by commentators on Indigenous education that culturally exclusive education practices lie at the very root of Indigenous under-representation in tertiary education, particularly in the sciences (Aikenhead, 2002; Bartlett et al., 2007; Howlett et al., 2008; Snively \& Williams, 2006). Identifying how such practices have come about is critical in the learning of how they can be transformed. For this paper it is also important for providing a broader context for exploring Canadian practices and recognising their significance.

The exclusive power generated by Western science's ontological claim of universal truths, rationality and objectivism has had profound ramifications for Indigenous peoples and their knowledges encapsulated within nation states via processes of colonisation (as experienced in the formation of Australia and Canada). The rationalising power found through the social construction of scientific universalisms is intimately linked to the politics and agenda of imperialism. Essentially, the power yielded through these assumptions has excluded a place for Indigenous knowledges. As Howitt and Suchet-Pearson, (2003, p. 2) maintain, it has displaced, devalued, and rendered Indigenous knowledge systems silent, while Western science entrenches its "universal" mechanism for self-legitimisation.

The colonial and imperialistic agendas of early governments entrenched the institutionalisation of Western science as the dominant way of knowing in public institutions, such as the university, through its assumed superiority over all "Other" ways of knowing. Foucault (1977, p. 47) argues that such positioning allows knowledge to be legitimised and thus made powerful. Education institutions such as the University exemplify the nexus of knowledge and power and constitute central mechanisms of power within society through their function of constructing, legitimatising, and disseminating "truths" (Berry, 1999, p. 76; Foucault, 1977, p. 47).

While relations between Indigenous peoples and the state have changed over time, Rose (1999, p. 182-3) argues that many power-knowledge dynamics generated by imperial and colonial assumptions have been "naturalised" (or normalised) in the structure and functioning of universities today. The internalisation of Eurocentric values extending from colonisation and Western science, is evident, for example, by the way universities continue to act from a basis of hierarchal governance with singular visions and homogenous knowledge applications (Battiste \& Henderson, 2000, p. 84). This orientation has manifested a process that Battiste and Henderson (2000, p. 85) call "cognitive imperialism". Here, Eurocentric knowledge and teaching methods are projected as being normative and ideal, with all other knowledge constructions being 
either falsified or marginalised. Such presuppositions have effectively devalued Indigenous cultures, voices, and ways of knowing, ultimately discounting them as legitimate ways of knowing for higher learning. Consequently, Wilson $(2004$, p. 3) discusses how dominant society has taught Indigenous peoples that their knowledge traditions are "inferior" to those of European origin, and that their ways are "incompatible with modernity and civilisation". Freeman (2006, p. 53) asserts that this cultural exclusion has led to a great loss of Indigenous peoples identity and consequently, the "under-utilization of their potential". As WattCloutier (2000, p. 114) contends:

Education is a means of learning the way a peoples prepare themselves for life ... All cultures have this, though form varies ... If programs are created that don't respect and challenge the full creativity and potential of people-then they will crush rather than liberate.

McLisky and Day (2004, p. 28) observed the exclusiveness of science education has also created common perceptions in Indigenous communities of Western science education being irrelevant and even damaging to their people as it is "disrespectful to Indigenous rights and sovereignty" through its opposition to Indigenous knowledge. They found that underlying these perceptions exists an intergenerational fear of science emerging from exclusion, colonisation and historically racist applications of science (McLisky \& Day, 2004, p. 38). However, Malatest et al. (2004, p. 34) argue:

[i]t's believed that Aboriginal students in sciencebased professions, especially health and natural resources, will increase as self-government increases ... Herman Michell of the First Nations University of Canada states that meaningful selfgovernment can only be exercised by a balanced pool of educated Aboriginal resource people.

Thus, some Indigenous education spokespeople strongly perceive that gaining expertise in the sciences forms a necessary "resource kit" for empowering Indigenous self-governance.

It is for these reasons, amongst others, that a place for Indigenous ways of knowing is advocated through Indigenous-centred education. Such a development requires that a space be provided at the cultural interface where the place of Western science and Indigenous knowledges can be negotiated. As Battiste and Henderson (2000, p. 87) advocate, these developments are critical for Indigenous peoples to be finally granted their sovereign right to exercise, transmit and grow from their own knowledge and heritage. Yet, there is a distinct lack of clarity about the capacity of tertiary science education to move beyond its Eurocentric foundations to embrace Indigenous knowledges, and what is needed for this to happen.

The place of Indigenous knowledges

Identifying the need for Indigenous science curriculum, within a historical and contemporary context, is but one step amongst many. Understanding the needs of such curricula is critical. By drawing from current literature a variety of measures were identified as being necessary for ensuring the appropriateness and accountability of Indigenised curriculum to Indigenous communities. These included: the embracing of ontological pluralism, the implementation of community-driven programs with inclusive curriculum, and that institutions undertake processes of reflexivity in order to confront limitations that may be imposed upon Other peoples and their ways of knowing within the academy. We would contend that reflexivity is essential and allows the negotiation of place for Indigenous ways of knowing in spaces that have been historically Eurocentric. These measures formed the criteria through which Canadian practices were analysed.

\section{Ontological pluralism}

For Indigenous and Western scientific ways of knowing to co-exist in science curriculum ontological pluralism must be embraced. Ontological pluralism, within this context, is only conceptually possible when Western science is realised outside its universal framework and in its social context of locality: time and place. The reasoning for this is succinctly discussed by Bhabha (1990, p. 209):

The difference of cultures cannot be something that can be accommodated within a universalist framework ... The assumption that at some level all forms of cultural diversity may be understood on the basis of a particular universal concept ... can be both very dangerous and very limiting in trying to understand the ways in which cultural practices construct their own systems of meaning and social organisation.

Including Indigenous knowledges in tertiary science education without challenging the dominance of Western science and embracing genuine ontological pluralism is problematic for Indigenous peoples as the legitimacy of Indigenous knowledge systems cannot be recognised. This inability precludes any meaningful negotiation of how the knowledge domain of science education is occupied. How then, can the cultural interface of Western science and other ways of knowing be made visible so that space can be negotiated for genuine ontological pluralism? Simply acknowledging the possibility of multiple knowledge systems is not 
enough. Moving beyond conceptual discussions, it is important to elucidate practical measures that enable ontological pluralism to be actualised.

\section{Community-driven programs with inclusive curriculum}

Curriculum that actively engages with Indigenous peoples and their ontologies is key for actualising ontological pluralism, as the creating of such a space forms an important mechanism for diffusing power from hegemonic structures. The embedding of Indigenous knowledge, whether or not it should proceed and on what terms, is for Indigenous peoples to define themselves. This is particularly important because developments in Indigenous education are grounded in the broader campaign for Indigenous rights and self-government (Richardson \& BlanchetCohen, 2000, p. 7). Thus, for Indigenous education to be culturally appropriate and empowering for Indigenous peoples it must be community-driven with inclusive curriculum practices.

Papillon and Cosentino (2004, p. v) emphasise that the shared histories of "disempowering policies" have created mistrust amongst Indigenous peoples towards education institutions. Howlett et al. (2008, p. 25) also stress that the possibility of knowledge appropriation is a concern to Indigenous peoples in considering the prospect of sharing their knowledge in Eurocentric institutions. Additionally, there also exists a real potential of Indigenous knowledge being viewed as an "untapped resource" for academia to capitalise upon in the devising of solutions for environmental problems, for example. Therefore, creating programs that are communitydriven with inclusive curriculum is an important step for negotiating a place in science education where Indigenous knowledge heritage is empowered and not further harmed. It is a central strategy for precluding Indigenous knowledge appropriation as Indigenous peoples can maintain control over their knowledge - what they choose to share, with whom and on what terms.

\section{Institutional reflexivity}

Williamson and Dalal (2007, p. 57) contend that negotiating a place for Indigenous knowledges at the cultural interface of Indigenous and Western scientific ways of knowing in educational institutions is a profoundly challenging and discomfiting process for many people. Primarily, this is because such a process requires critical self-examination and personal responsibility for how we have internalised the dominant discourse of Western science. LaFrance (2000, p. 102) refers to this as a process of reflexivity a process of self-confrontation with the limitations one imposes on other ways of knowing.
The capacity of tertiary science institutions to undertake processes of reflexivity is crucial for meaningful negotiation to occur at the cultural interface of tertiary science education. In this research it is argued that it is the responsibility of those positioned within traditionally Eurocentric education institutions to undertake a process of reflexivity to empower a place for ontological plurality in science education, and thus, for Indigenous ways of knowing. In this process, Rose (1999, p. 182-3) stresses the importance of educators remaining vigilant and discerning about possible entrenched colonial practices that are easily overlooked:

This embeddedness may conceal, naturalize, or marginalize continuing colonizing practices ... Furthermore, practices of colonization are so institutionalised in political and bureaucratic structures and policies, that they are almost unnoticed.

Practical measures embracing ontological pluralism in tertiary science, which challenge the dominance of Western science, have been initiated in some Canadian universities. Drawing upon their experiences and lessons learned is valuable for learning how a place for Indigenous knowledges can be negotiated at the cultural interface here in Australia. As mentioned, some of the key aspects of culturally appropriate Indigenous-centred curriculum identified above form the criteria by which Canadian practices were analysed; that programs be community-driven with inclusive curriculum, that a discernable ontological shift occurs, away from ontological homogeneity and towards pluralism, and finally, that housing universities are reflexive in order to accommodate these developments. Additionally, this analysis is discussed with regard to factors that have empowered the Indigenising of science curricula, along with sights of tension at the cultural interface where culturally appropriate Indigenised curricula has been limited, and how these tensions can be negotiated. Finally, based upon Canadian experiences, the capacity of Indigenised curriculum to increase Indigenous student representation in tertiary science studies was also considered.

The theoretical framework previously presented guided this analysis. The constructionist thesis facilitated the analysis of the construction of the knowledge domain of tertiary science education: whether the Indigenous Environmental Studies Program (IES) and Integrative Science Program (IS) are exclusive or inclusive of Indigenous ways of knowing. Concurrently, Foucauldian perspectives guided the analysis of the role of knowledge and power in negotiating tensions at the cultural interface of Indigenous and Western scientific ways of knowing in this domain. Specifically, the research focussed 
upon how knowledge in this domain is entrenched in, or emancipated from, hegemonic structures, and how power at this site is empowering or challenging efforts to Indigenise curriculum. The analysis, informed by these insights, concluded that Indigenised curriculum can increase Indigenous representation in tertiary sciences studies, however, this is contingent upon its capacity to be culturally appropriate in practice - to meet the criteria stated above.

Canadian practices in Indigenising tertiary science curriculum

Trent University, located in Peterborough, Ontario, and Cape Breton University in Sidney, Nova Scotia, are both home to Indigenised science programs.

\section{Indigenous environmental studies}

Indigenous Environmental Studies (IES) is situated at Trent University. It is interdisciplinary in its approach to environmental studies, and brings together Indigenous and Western environmental perspectives (Trent University, 2008). Students can study IES as a specialisation within a Bachelor of Arts or Bachelor of Science. Alternatively, Indigenous students can study IES as a Diploma (Trent University, 2008). The program is cross-listed between the Environmental and Resource Science/Studies Program, and the Department of Indigenous Studies.

\section{Integrative sciences}

Cape Breton University is home to Integrative Sciences (IS). The program is offered through the School of Science and Technology, and is one of three concentrations within the Bachelor of Science Community Studies (Cape Breton University, 2008). Central to IS is the bringing together of "scientific knowledges and ways of knowing from Indigenous and Western world views to provide science education" (Cape Breton University, 2008).

It is important to note that although the two Canadian programs are discussed simultaneously, comparisons regarding program merits and value were not made. While they both bring together Indigenous and Western scientific ways of knowing, these programs are distinct in their approach and focus. Critically, it is acknowledged that there can be no correct, singular Indigenous science education model, as there exists incredible diversity amongst the many distinct cultural groups that the use of the term "Indigenous". In this respect, this research concurred with Escobar's (quoted in Howitt \& Suchet-Pearson, 2003) assertion that:

instead of searching for grand alternative models or strategies, what is needed is the investigation of alternative representations and practices in concrete local settings ... One must ... resist the desire to formulate alternatives at an abstract, macro level.

To secure the anonymity of those who volunteered to participate in this study participants are referred to with the pseudonyms outlined in Table 1 throughout this discussion.

\section{Factors empowering the Indigenising of tertiary science education}

It was found that direct Indigenous community involvement in the programs, along with the philosophical foundations of the programs were significant factors that evidently strengthened the programs by establishing a privileged place for Indigenous peoples and their ways of knowing.

\section{Community inclusion}

Through all stages, IES has received direct support from, and space has been provided for, elders and other community peoples to inform the program's curriculum (Phil). In 1996 "elders and traditional peoples developed the content of the program", in accordance to what they felt needed to be learnt (Phil). Here, Phil brought together elders, community peoples and academic staff to develop an IES program that could "embed science and Indigenous ways of knowing in the curricula" (Phil). These courses provide multidisciplinary approaches to Indigenous environmental science which include: integrating Western scientific understandings with Indigenous perspectives, knowledges, understandings, world-

Table 1. Volunteer pseudonyms and roles.

Pseudonym

Role

\begin{tabular}{|l|l|}
\hline Jane & Senior faculty staff of IS at Cape Breton University \\
\hline Sarah & Faculty staff at IS \\
\hline Peter & IS student \\
\hline Katrina & IS student \\
\hline Phil & Senior faculty staff IES at Trent University \\
\hline Tom & IES faculty staff \\
\hline
\end{tabular}


views and philosophies, along with health, political, socio-economic and ethical issues as they pertain to Indigenous communities. Furthermore, the director of IES is a citizen of the Haudenosaunee; The Six Nations Confederacy from Ohsweken, at the Grand River Territory, and has long demonstrated a strong commitment to his community (Student International Health Initiative, 2006). His experience, positioning and involvement in the program demonstrate that the driving impetus for the development of IES has come directly from community (Student International Health Initiative, 2006).

The IS program at Cape Breton University was likewise driven by community needs in its developmental stage. Jane expressed: “That's how it all started, the community, the elders were concerned that there were not any students from their community going into the sciences" (Institute for Integrative Science Health, 2006). Various members of the Mi'kmaq community expressed their hopes that "one day the educational system would recognize Indigenous science alongside Western science" (Bartlett et al., 2007, p. 5). In the development of the program and its guiding principles, IS staff spoke of how they had "no model to begin with as our program is a first of its kind' and therefore, they 'relied heavily upon Eskasoni elders" (Jane).

Involving community elders in the courses is stated as a central aim on the program's website (Jane). Staff stressed that "a program like this needs to be taught side by side", ideally in the classroom with elders and community representatives and Western science (Jane). Due to unforeseen health challenges, the degree of elder involvement has been limited in the program. To compensate for this, various initiatives have been arranged. For example, student visits to communities, along with student engagement with community-based projects. Additionally, a Mi'kmaq linguist was brought into the classroom, however, restrictions were met here with university funding for double-staffing.

\section{Program philosophies}

The underlying philosophies of the two programs enabled these developments and demonstrates that IES and IS were constructed from conceptual frameworks that assume ontological pluralism as their foundation.

A key understanding of the program is that there exists two separate bodies of knowledge that are distinct: Western science and Indigenous knowledges. The purpose of the program is to develop a working relationship between the two (Phil). Phil suggested that the program should be thought of as an integrative process that interlinks different ways of knowing through holistic learning approaches. A program that creates new tools out of knowledge exchange to create new solutions and capacity building in communities, from the understanding that "good planning in communities doesn't come through bureaucratic agencies; it comes from within communities themselves" (Phil). On a similar vein, the central goal of IES is to strengthen the capacity of communities to self-govern environmental and health problems that affect their communities in culturally appropriate ways to their people (Phil).

For IS at CBU, an underlying philosophy and working principle that was given to the program by one of the main elder's involved is the concept of "Two Eyed Seeing" (TES). In Bartlett et al. (2007, p. 14), the definition and purpose of TES is described as:

learning to see from one eye with the strengths of (the best in) Indigenous knowledges and ways of knowing, and from the other eye with the strengths of (the best in) Western knowledges and ways of knowing, and to using both these eyes together, for the benefit of all. Thus, TwoEyed Seeing intentionally and respectfully brings together our different knowledges and ways of knowing, to motivate people, Aboriginal and nonAboriginal alike, to use all our gifts so we leave the world a better place and not compromise the opportunities for our youth (in the sense of Seven Generations) through our own inaction.

Ultimately, a major aim of the IS program is to bring:

together Indigenous sciences and ways of knowing with Western sciences and ways of knowing, beginning in the post-secondary science education arena and then expanding to the science arenas of research, applications, and outreach to youth and community (Bartlett et al., 2007, p. 2).

From this discussion it is evident that the IES and IS programs embody the criteria specified earlier, which required programs to be community-driven with inclusive curriculum and to demonstrate an ontological shift in the sciences, moving away from homogeneity and towards ontological pluralism. These criteria are fundamental to Indigenising curricula because they challenge the hegemony of Western science in tertiary education and negotiate a place for Indigenous knowledge systems. In this regard they constitute empowering factors for the Indigenising of curriculum and their implications are significant. By being founded on ontological pluralism, IES and IS have constructed a new knowledge discourse at the cultural interface of science education. This discourse assumes a relationship between Western science and Indigenous ways of knowing that is based upon mutual respect. The power inherent in this new discourse requires knowledge to be emancipated from hegemonic structures by privileging a place for Indigenous voices and knowledge systems. From this 
position, science education extending from the new knowledge discourse is capable of accommodating the historical and political context of Indigenous education. Furthermore, it facilitates a more honest representation of knowledge in science studies. While program experiences demonstrate that challenging the dominant power is possible, other experiences indicated that the extent of their success was limited due to the entrenched hegemony of the dominant knowledge discourse.

The mere fact that these programs exist is indicative of the support they receive from their housing university's. For the IES program in particular, strong support is received at a faculty level, as the program is cross-listed with the Environmental Resource Science/ Studies department. Additionally, there is now one subject cross-listed with the nursing faculty. For the IS program, however, Jane discussed how the science department is not supportive of IS - they "didn't want it" and "have not been supportive ... they have not tried to understand us ... [but] these days we are tolerated by the science department" (Jane).

\section{Tensions at the cultural interface}

Tensions at the cultural interface of Indigenous and Western scientific knowledge were evident where university structures and regulations clashed with the needs of the programs. At these sites, the full expression of Indigenised curriculum is found to be contested. The most prevalent cause of tension for both programs is the higher administrative divisions of their housing universities, whereby program support was found to be highly conditional (Jane, Phil). Jane from IS identified that this was due to "the mindset of the university". Jane elaborated that a large portion of the university community, though not all, "don't want to understand [IS] ... and more precisely, didn't make an effort to understand" (Jane).

Conditional financial support formed a significant limiting factor for both programs. Here, it was revealed that financial support for both programs was contingent upon their fulfilment of university student enrolment quotas. For IES, Trent University has maintained an interest in the program achieving greater student numbers, and support for the program is based upon this criteria (Phil). Paradoxically, Phil explained how they require more funding to hire new faculty and develop courses in order to increase their capacity for attracting more students into IES. Phil explained that without the deeper support from the university, the program has not had the resources that it requires to succeed in its original goals that the elders and other community people requested. For example, an issue for the program has been how to create the necessary funding to bring elders directly into the program. Phil stressed that, "ideally, that's how it should be: bringing elders into courses and then also bringing students out of campus to communities". The necessity of meeting community needs and including Indigenous peoples in the program, through community-based projects that seek engagement on community terms, appeared to be a central theme throughout the workshop. Regarding this, Phil identified a problem with accommodating the structures of the university while also retaining the ability of the program to meet the pragmatic needs of communities.

Similar to IES, it was discussed that a great impediment for IS receiving necessary funding to meet their program goals is getting what the university considers to be appropriate student numbers in courses. Jane elaborated that the university "doesn't recognise that Indigenous participation in science courses should be treated and seen differently to non-Indigenous students". Indigenous students are "grossly under-represented", and therefore, "even having one [Indigenous student] in a science program is a major achievement". From this position, IS staff stressed that the university "needs to recognise the context of this program - not the program in isolation - then see the needs that it has ... [and then] consider what should be seen as appropriate or successful [for Indigenous student] enrolment and retention in IS" (Jane).

Likewise, it was discussed how the university's perception of IS has been stifling, as "to get the necessary finances to run the program the way we want to, getting numbers [enough students] is key ... this has been an ongoing problem for this program". It was mentioned that "clashes" have been experienced in negotiating the needs and expectations of the communities with those of the university. Jane emphasised that "the community wants real stuff, like actions, workshops - not papers ...".

Dimmock and Walker (1998, p. 565) contend that developments in multicultural education have immediate implications for the administrative management of education institutions - particularly the "knowledge base" from which they extend. Conditional financial support for both programs are a symptomatic of the dominant knowledge discourse. Consequently, it has resulted in certain components of the IES and IS programs being compromised. For instance, program requirements for double staffing and the inclusion of elders so that programs are taught "side by side" could not be fulfilled (Jane, Phil). Limited financial resources also restricted both programs in being developed as originally intended. For example, IES staff members were limited in the amount of time they could spend in community, despite the fact that maintaining strong community relations is foundational to their programs.

The university has embedded rules and regulations that are not capable of recognising the needs of others A ramification of this is that the university support for 
Indigenising science curriculum at TU and CBU is compromised. In both cases, the university has failed to be reflexive enough in order to confront the limitations it imposes upon Indigenous ways of knowing. These universities have not embraced genuine ontological pluralism; rather, they have maintained practices that continue to entrench the hegemony of Western scientific knowledge systems. This entrenchment effectively constrains the extent to which programs can negotiate a place for Indigenous ways of knowing at the cultural interface of tertiary science education. The complications inherent to the process of challenging hegemonic structures within tertiary institutions is acknowledged by Goss's (1996, p. 248) warning about so-called post-colonial developments, whereby there is a "desire to move beyond colonialism" yet a lack of commitment to "address adequately which historical influences and conditions remain".

Without a genuine commitment to ontological pluralism at the institutional level, there exists a danger that the Indigenous knowledge embedded in Indigenised programs could be appropriated by the hegemonic structures. Thus we see that attempts to Indigenise the curriculum can be paradoxical. Indigenous peoples are provided space for self-determination, but as Hughes (1995, p. 382) explains, this autonomy is contingent upon them "not disobeying the ultimately governing system". Under such a guise, education for Indigenous peoples risks becoming another tool for assimilation.

Despite these real dangers, the inclusive structures of the IES and IS programs ensure that control is maintained by Indigenous peoples over what they choose to disclose and on what terms. Thus, Indigenous participants in the programs secure their ownership over their knowledge systems. These programs, however, are still governed by their housing universities, institutions that are not reflexive. The programs are consequently restricted by this. Given the challenges and tensions that IES and IS have experienced at the cultural interface of science education, it is apparent that genuine ontological pluralism requires universities to be reflexive. To be reflexive, we argue that a privileged place needs to be constructed for Indigenised curriculum. Indigenised programs have different needs: for staffing, in their structure, teaching, and for maintaining their programs so as to fulfill community needs. These programs also contend with different challenges, which arise from the type of entrenched historical disparities previously discussed. Mainstream programs do not experience such challenges, nor do they have the same needs. The generic allotting of equal support and space for Indigenised programs is therefore not adequate. However, Canadian practices offer hope to the Australian context as both IES and IS have been successful in many aspects of developing culturally appropriate Indigenisied curriculum's. Furthermore, poignant strategies for negotiating these challenges were also identified.

\section{Negotiating tensions}

Utilising Foucauldian perspectives on knowledge and power as both positive and negative forces, there is hope that the hegemonic position of Western science can be challenged. Thus, empowering or hegemonic outcomes can emanate from negotiating the tensions at the cultural interface. Foucault (1977, p. 47) argues that education is a mechanism of power. For Indigenised curriculum it is a mechanism for generating greater understanding, acceptance and support of Indigenous perspectives and ways of knowing. In doing so, this mechanism can unsettle the dominance of Western ontological perspectives

Education was proposed by members from both programs as a key strategy for overcoming program limitations. In particular, both IES and IS staff proposed that educating the educators about the broader context of the programs is essential for overcoming challenges that arise from the university's "mind-set" and lack of understanding (Phil, Jane). Education was also utilised by IS as an avenue for increasing Indigenous student access and awareness of the program via the Mi'kmaq Science Advantage Program (MSAP): an alternative entrance program ran by the on-campus Mi'kmaq College to assist Indigenous students who do not have relevant science training (Jane).

In addressing the limitations imposed on these programs, however, Kirkness (1997, p. 10) reminds us that, "no change can happen overnight for the decades of colonial policies have left deep scars that impact on all programming for First Nations". It must be recognised that it may take a considerable amount of time before those within the university, who continue to entrench key sites of tension, are capable of looking beyond the homogenic confines of the dominant knowledge discourse of Western science. In acknowledging the time and patience required for change, the utility of Phil's recommendations for overcoming financial constraints via the sourcing of external funding from industry and government sectors is appreciated. Effectively, alternative funding could facilitate staff and community agency to undertake more substantial negotiations at the cultural interface in order to further develop their programs, despite restrictions imposed by their universities. This is an important component of Indigenous self-governance. However, as Phil commented, such partnerships can also be problematic.

\section{Indigenous student representation}

In practice, both programs have significantly contributed to Indigenous student representation in tertiary science courses. However, their achievements 
are most visible when situated within the broader historical and contemporary context of Indigenous under-representation in the sciences. In October 2007, the IES program at TU had an enrolment of approximately 72 students in its courses. Of these, over $50 \%$ were Indigenous. As a result of the IS program at CBU, Indigenous student representation in the sciences has risen from "near zero to about 115 Mi'kmaq students who have experienced a first year of postsecondary science". Of these, $44 \mathrm{Mi}$ 'kmaq students are classified as "graduated, enrolled, and/or paused with intent to return", with six new graduates in late 2006, and a further four expected in 2007 (Bartlett et al., 2007, p. 9).

Informative perspectives regarding Indigenous student representation in the sciences were shared by the two IS students. For example, Katrina explained that after taking an IS elective, she changed her specialisation to IS studies because she found the program to have a "comfortable atmosphere". Although she had previously "never thought of studying it (science)", it was "the cultural part of it" that had "made it more comfortable" for her to study. Similarly, Peter shared that he had been used to the format and conduct of typical Western education: how things were taught along with expectations for student engagement, but that studying in IS was a very different experience. He discussed how the practical component of IS had been key for him as it was the first time his educational experience was cultural relevant. He found that he "could relate to it" as the program was compatible with his Dad's teachings about the land and his ways (Peter).

Paralleling these achievements, Indigenous centred programs across Canada have seen a marked rise in Indigenous participation in education across all levels of schooling, and are considered to be at the heart of culturally appropriate solutions to addressing Indigenous education under-representation (Hampton, 2000; Castellano et al., 2000). For example, in an analysis of seven Canadian programs working in partnership with Indigenous peoples and communities to implement Indigenised curriculum, all exhibited a "student retention and program completion ... [of] twice the national average for Aboriginal postsecondary training" (Malatest et al., 2004, p. 32).

From interactions with staff of both programs it is clear that the issue of Indigenous student participation in their courses moved well beyond meeting university enrolment quotas by filling seats. This is obvious when considering a priority for both programs is to meet the needs and interests of communities first. Phil from IES also commented on the importance of nurturing the real needs of the students themselves. He emphasised, that the focus of IES is in "helping Indigenous people do what they need to do". Helping Indigenous students either "become medicine people or an elder, moving outside of the academy if that's where their path is, or helping them on to a PhD" (Phil). While education is important, it is but one avenue amongst many for strengthening Indigenous self-government, and so caution needs to be exercised by educators to ensure that that the real needs of Indigenous students are not overlooked in the pursuit of increasing Indigenous student retention.

\section{Summary}

The Indigenising of tertiary science curriculum denotes an emerging field, both in practice and research, within the Australian context. This is primarily due to the fact that no Australian university has yet created an Indigenised science course or program to date. Consequently, very little research has been conducted in this field in Australia and yet the research presented in this paper confirms that there is much to be learnt regarding tensions and opportunities that exist at the cultural interface where Western knowledge meets Indigenous knowledges.

Both IES and IS fulfilled the first three aspects of the criteria which required programs to be community-driven, with inclusive curriculum, and demonstrated the existence of ontological pluralism. These were evidently empowering factors for Indigenising curricula. Foundational to these criteria were the two programs construction of a new knowledge discourse based upon ontological pluralism. Critically, this discourse empowers the place of Indigenous knowledge in science education by privileging a place for Indigenous knowledge systems. The last criteria, which required housing universities to be reflexive in order to accommodate Indigenous centred programs, was only met in part. Despite the space allocated to these programs within their housing universities, the conditional financial support that the programs received formed a major impediment to the programs fulfilling their goals and meeting community needs - creating a major site of tension at the cultural interface. Tensions at the cultural interface of Indigenous and Western scientific knowledge systems ultimately extended from ontological collisions between the programs and their housing universities. These were the result of the universities ontological foundations, which privileged the dominant knowledge discourse of Western science. To negotiate tensions extending from the "mind set" of the university, education was the main mechanism proposed, and utilised, by staff of both programs. Additionally, Phil from IES emphasised obtaining funding avenues external to the university for overcoming impediments.

Overall, the central finding of our analysis is that Indigenised curriculum can increase Indigenous student representation in tertiary science studies, but not without encountering problems. There needs to be institutional acceptance of ontological pluralism in 
order for fully Indigenised programs to emerge. This insight is important to any future attempts in Australia to Indigenise university science curricula.

While the findings of this research identify some pertinent insights, the breadth and depth of the research was considerably limited by time, research scope and financial constraints. For these reasons it is our hope that this research will be considered a significant background report for informing future research in this field. As we conclude, despite their challenges Canadian practices constitute commendable examples for science education elsewhere by forging a place for Indigenous ways of knowing at the cultural interface of science education.

\section{Acknowledgements}

We express our gratitude to the wonderful participants at Trent University and Cape Breton University who allowed this research to take place by sharing their time, perspectives and knowledge with us.

\section{References}

Aikenhead, G. (2002). Integrating Western and Aboriginal sciences: Crosscultural science teaching. Research in Science Education. Retrieved 11 January, 2008, from www.usask.ca/education/people/aikenhead/ risearticle.htm.

Allen, J. (2003). A question of language. In M. Pryke, G. Rose, \& S. Whatmore (Ed.), Using social theory: Thinking through research (pp. 11-27). London: Sage Publications.

Barnes, B., \& Bloor, D. (1982). Relativism, rationalism and the sociology of knowledge. In M, Hollis \& S. Lukes (Ed.), Rationality and relativism (pp. 21-47). Oxford: Blackwell.

Bartlett, C., Marshall, M., \& Marshall, A. (2007). Integrative science: Enabling concepts within a journey guided by trees holding hands and two-eyed seeing. Two-eye seeing knowledge sharing series, 1. Retrieved 5 June, 2007, from www.integrativescience.ca.

Battiste, M., \& Youngblood Henderson, J. (2000). Protecting Indigenous knowledge and heritage: A global challenge. Saskatoon: Purich Publishing.

Berry, T. (1999). The great work: Our way into the future. New York, NY: Bell Tower.

Bhabha, H. K. (1990). Nation and narration. London: Routledge.

Blackburn, S. (2005). Oxford dictionary of philosophy (2nd ed.). New York, NY: Oxford University Press.

Cajete, G. (2000). Native science: Natural laws of interdependence. New Mexico: Clear Light Publishers.

Cape Breton University. (2008). Integrative science brochure. Retrieved 23 February, 2008, from http://marcatodigital.com/iish/pdf/integrative science_brochure.pdf.

Castellano, M. (2004). Ethics of Aboriginal research. Journal of Aboriginal Health, (January), 98-114.

Castellano, M. B., Davis, L., \& Lahache. (2000). Aboriginal education: Fulfilling the promise. Vancouver: UBC Press.

de Vaus, D. (2001). Research design in social research. London: Sage Publications.
Department of Education, Science and Training (DEST). (2006). Students 2005: Selected higher education statistics, Commonwealth of Australia. Retrieved 2 November, 2006 from www.dest.gov.au/NR/rdonlyres/ F1331710-F793-4E81-8867-B5FAF1AEC4DE/13781/2005_student_full year_data.pdf.

Department of Education, Science and Training (DEST). (2008). Indigenous participation in higher education, Commonwealth of Australia. Retrieved 23 February, 2008, from http://www.dest.gov.au/sectors/indigenous education/policy_issues_reviews/key_issues/indigenous_participation_ in_higher_education.htm.

Department of Indian and Northern Affairs Canada (2002, November). Aboriginal research conference, Ottawa, Canada.

DiGregorio, K. D., Farrington, S., \& Page, S. (1997, NovemberDecember). Listening to our students: Understanding the factors that affect Aboriginal and Torres Strait Islander students' academic success. Paper presented at the annual conference of the Australian Association for Research in Education, Brisbane, Queensland, Australia.

Dimmock, C., \& Walker, A. (1998). Comparative educational administration: Developing a cross-cultural conceptual framework. Educational Administration Quarterly, 34(4), 558-595.

Foucault, M. (1978). Discipline and punish: The birth of the prison. New York, NY: Pantheon.

Foucault, M. (1995). Discipline and punish (Vintage Books Ed.) New York, NY: Vintage Press.

Freeman, K. (2006). If only my eyes were different: The loss of identity and the under-utilization of black children's educational potential-Rethinking Social justice and assimilation. Review of Education, 52, 49-65.

Gergen, K. J. (1994). Realities and relationships: Soundings in social construction. Cambridge: Harvard University Press.

Goss, J. (1996). Postcolonialism: Subverting whose empire? Third World Quarterly, 17(2), 239-250.

Hampton, E. (2000). First Nations controlled University education in Canada. In M. B. Castellano, L. Davis and Lahache (Ed.), Aboriginal education: Fulfilling the promise (pp. 208-224). Vancouver: UBC Press.

Hooley, N. (2000, December). Education research: Towards an optimistic future: Reconciling Indigenous and Western knowing. Paper presented at the annual Australian Association for Research in Education Conference (AARE) Sydney, New South Wales, Australia.

Howitt, R., \& Suchet-Pearson, S. (2003). Spaces of knowledge. In M. Domosh, S. Pile \& N. Thrift (Ed.), Handbook of cultural geography (pp. 557-569). London: Sage Publications.

Howlett, C., Seini, M., Matthews, C., Dillon, B., \& Hauser, V. (2008). Retaining Indigenous students in tertiary education: Lessons from the Griffith School of Environment. The Australian Journal of Indigenous Education, 37, 18-27.

Hughes, I. (1995). Dependent autonomy: A new phase of internal colonialism. Australian Journal of Social Issues, 30(4), 367-388.

Institute for Integrative Science and Health. (2006). Bringing together Aboriginal and Western scientific knowledges, Two-eyed seeing: Knowledge sharing series, Video 1, Cape Breton University.

Kenny, C. (2004). A bolistic framework for Aboriginal policy research: Status of women. Ottawa: Status of Women. Retrieved 25 February, 2008, from http://dsp-psd.pwgsc.gc.ca/Collection/SW21-114-2004E.pdf. 
Kirkness, V. (1997). Our people's education: Cut the shackles; cut the crap; cut the mustard. Canadian Journal of Native Education, 22(1), 10-15.

LaFrance. B. T. (2000). Culturally negotiated education in First Nations communities: Empowering ourselves for future generations. In M. B. Castellano, L. Davis and Lahache, Aboriginal education: Fulfilling the promise (pp. 101-114). Vancouver: UBC Press.

Latour, B. (1993). We have never been modern. Cambridge: Harvard University Press.

Malatest and Associates Ltd. (2004). Aboriginal peoples and post-secondary education: What educators have learned. Montreal: Canadian Millennium Scholarship Foundation.

Matthews, C., Howlett, C., Dillon, B., \& Seini, M. (2006). Questioning the links between information provision and the retention of commencing Indigenous students within the science and technology group. Unpublished report to the Student Orientation and Engagement Committee.

McLinsky C., \& Day, D. (2004). Black and white science: Encouraging Indigenous Australian students into University science and technology. Sydney, NSW: University of Sydney.

Mishler, E. G. (1986). Research interviewing: Context and narrative. Cambridge: Harvard University Press.

Nakata, M. (2007). The cultural interface. The Australian Journal of Indigenous Education, 36, 7-14.

Papillon, M., \& Cosentino, G. (2004). Lessons from abroad: Towards a new social model for Canada's Aboriginal peoples. Canadian Policy Research Networks, Social Architecture Papers Research Report F40. Ottawa: Canadian Policy Research Networks.

Richardson, C., \& Blanchet-Cohen, N. (2000). Survey of post-secondary education programs in Canada for Aboriginal peoples. Report prepared for UNESCO January 2000 by Institute for Child Rights Development and First Nations Partnership Program. Victoria: University of Victoria Press

Rose, D. B. (1999). Indigenous ecologies and an ethic of connection. In N. Low (Ed.), Global ethics and environment (pp. 175-187). London: Routledge.

Smart, B. (1986). The politics of truth and the problem of hegemony. In D C. Hoy (Ed.), Foucault: A critical reader (pp. 157-174). Oxford: Blackwell.

Smith, L. T. (1999). Decolonizing methodologies: Research and Indigenous peoples. Dunedin, New Zealand: University of Otago Press.

Snively, G. (2006). Honoring Aboriginal science knowledge and wisdom in an environmental education graduate program. In C. R. Menzies (Ed.), Traditional ecological knowledge and natural resource management (pp. 195-220). London: University of Nebraska.

Snively, G., and Williams, L. (2006). The Aboriginal knowledge and science education Research Project. Canadian Journal of Native Education, 29(2), 229-244.

Student International Health Initiative. (2006). Community healing. Aboriginal health Conference: Speakers biographies and abstracts, Student International Health Initiative. Retrieved 9 October, 2007, from http://www. msu.mcmaster.ca/clubs/sihi/bios.html.

Trent University. (2008). Indigenous Environmental Studies Program Brochure. Retrieved 23 February, 2008, from www.trentu.ca/ies/documents/ IESBrochurefinal.pdf.

Watt-Cloutier, S. (2000). Honouring our past, creating our future: Education in Northern and remote communities. In M. B. Castellano, L. Davis and
Lahache (Ed.), Aboriginal education: Fulfilling the promise (pp. 114-128). Vancouver: UBC Press.

Williamson, J., \& Dalal, P. (2007). Indigenising the curriculum or negotiating the tensions at the cultural interface? Embedding Indigenous perspectives and pedagogies in a university curriculum. The Australian Journal of Indigenous Education, 36S, 51-58.

Wilson, W. A. (2004). Indigenous knowledge recovery is Indigenous empowerment. American Indian Quaterly, 28(3/4), 359-372.

\section{About the authors}

Vivian Hauser has recently commenced $\mathrm{PhD}$ studies at Griffith University with a primary research interest in identifying a decolonising standpoint for non-Indigenous educators in tertiary education. Her research is based in Canada, where she currently resides.

Catherine Howlett is a Lecturer in Griffith School of the Environment, Griffith University. Cathy's PhD examined the role of the state in mineral negotiations involving Indigenous people, focussing on Century Mine in North West Queensland. Her research interests include Indigenous peoples and mineral development, Indigenising university curricula, Indigenous water rights and Indigenous people and environmental management.

Chris Matthews is a traditional owner within the Quandamooka Nation. Chris has a PhD in applied mathematics from Griffith University and is currently conducting research into Indigenising of science and mathematics curricula within higher education as well as in secondary and primary education. 
